\title{
Effects of Familial Support on Parenting Efficacy Among Vietnamese Married Immigrant Women in Rural Korea: Sequential Mediation Effects of Social Participation and Psychological Well-being
}

\author{
In Ok Park ${ }^{1}$, Ung Im Park ${ }^{2}$, Eun Gyoung Lee ${ }^{3}$ \\ M. A., Department of Family Environment and Welfare Studies, Andong National University, Andong, Korea ${ }^{1}$ \\ Professor, Department of Family Environment and Welfare Studies, Andong National University, Andong, Korea ${ }^{2}$ \\ Researcher, Ewha Institute of Social Sciences, Ewha Womans University, Seoul, Korea ${ }^{3}$

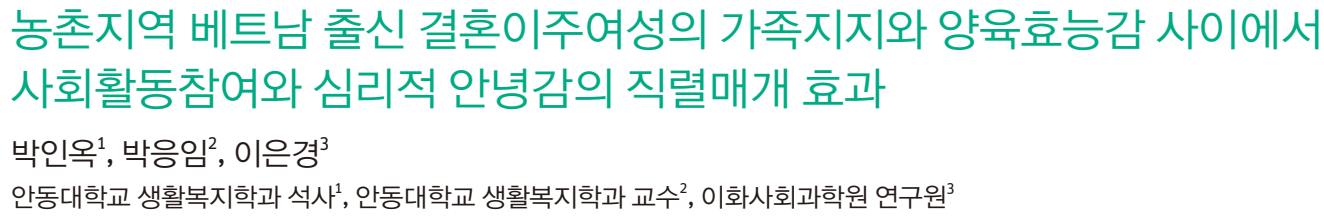

Objectives: This study considers the direct effects of familial support, social participation, and psychological well-being on the parenting efficacy of Vietnamese married immigrant women in rural South Korea. It also examines the indirect effects of social participation and psychological wellbeing, which mediate familial support and parenting efficacy.

Methods: Questionnaires were administered to 198 married immigrant women from Vietnam who resided in rural communities across 20 cities in 9 provinces of South Korea, and data were analyzed to examine sequential mediation effects among variables using PROCESS MACRO methods.

Results: Firstly, familial support had significant direct effects on parenting efficacy. Secondly, familial support indirectly affected parenting efficacy by mediating psychological well-being and yielding sequential mediation effects on social participation and psychological well-being.

Conclusion: These findings indicate that it is necessary to adopt an integrated approach when analyzing the parenting efficacy of specific communities that considers personal psychological variables, familial relationships, and social relationships; this will lead to a more comprehensive understanding of and implications for the parenting efficacy of Vietnamese married immigrant women, who comprise the majority of rural residents.

Keywords: married immigrant women, familial support, social participation, psychological wellbeing, parenting efficacy

\section{Introduction}

Ministry of Gender Equality and Family (2018, 이하 MOGEF)의 다문화가족 연도별 통계에 의하면 2017년 다문화 가족의 수

Corresponding Author: Ung Im Park, Professor, Department of Family Environment and Welfare Studies, Andong National University, 1375, Gyeongdong-ro, Andong-si, Gyeongsangbuk-do, Korea

E-mail: ungim@anu.ac.kr
는 32만 가구이며, 가구원수는 96만명으로 추정되고 있다. 외 국인과 결혼하는 추이는 2011년 이후 다소 감소되는 경향을 보이고는 있으나, 여전히 $7.9 \%$ 의 비율을 보이고 있으며 이 중 한국 남성과 외국인 여성이 결혼하는 비율이 $71.4 \%$ 를 차지하

(C)The Korean Association of Child Studies

This is an Open Access article distributed under the terms of the Creative Commons Attribution Non-Commercial License (http:// creativecommons.org/licenses/by-nc/4.0) which permits unrestricted noncommercial use, distribution, and reproduction in any medium, provided the original work is properly cited. 
고 있다(MOGEF, 2018). 이들 중 외국인의 국적별 혼인률을 보면 2016년부터 베트남 출신이 중국 출신보다 앞서기 시작 하여 2017년 현재 $36.1 \%$ 의 가장 높은 비율을 차지하고 있다 (Statistics Korea, 2018). 베트남 출신 결혼이주여성들은 다른 국 가의 이주여성에 비해 학력과 경제적 수준이 낮고, 배우자와 의 나이 차이가 많으며, 한국어 능력이 부족하고 친족, 이웃 간 의 교류와 자조집단 참여 등의 사회교류도 부족한 것으로 나 타났다(Seol \& Yoon, 2008). 또한 이들은 양육스트레스가 높고 양육효능감 수준이 더 낮은 것으로 보고되고 있다(J. Kim, Oh, Yoon, \& Lee, 2009; S. M. Lee \& Lee, 2010; Oh \& Oh, 2018). 한 편 국제결혼을 많이 하는 남성들은 우리사회의 농촌지역이나 도시주변부에 거주하고 있으며, 그 중에서도 도시지역에 거 주하는 결혼이주여성들보다 농촌에 거주하고 있는 이들이 문 화적 차이를 더 많이 경험하는 것으로 나타났다(Chung et al., 2016). 이러한 현상들을 종합해 볼 때 농촌지역에 거주하고 있 는 베트남 결혼이주 여성들에 대한 연구가 다문화가족의 연구 에서 우선적으로 이루어져야 함에도 불구하고 지금까지 이들 에 대한 연구는 많이 부족한 실정이다. 따라서 본 연구에서 농 촌지역에 거주하는 베트남 출신 결혼이주여성을 대상으로 연 구를 실시하고자 한다.

일반적으로 결혼이주여성들이 한국생활에서 겪는 어려 움으로 자녀양육 및 교육문제를 호소하고 있다(Chung et al., 2016). 특히 5세 이하의 자녀가 있는 다문화가족의 $77.4 \%$ 가 부모역할 수행에 어려움이 있으며 학령기 자녀가 있는 경우 $76.8 \%$ 가 학부모로서 어려움이 있다고 응답하였다(Chung et al., 2016). 결혼이주여성들이 자녀양육을 어려워하는 원인을 살펴보면 대부분의 결혼이주 여성들은 한국생활 적응과 자녀 양육이 같은 시기에 거의 동시적으로 이루어져 한국사회의 언 어와 문화에 제대로 적응하지 못한 상태에서 오는 심리적인 혼란과 자녀양육의 어려움을 한꺼번에 경험하기 때문인 것 으로 나타났다. 이들은 한국문화에서 적절한 양육 및 교육방 법을 모르고 자녀양육을 도와줄 사람이 없으며, 자녀와 의사 소통의 어려움, 학습지도와 관련된 어려움 등 다양한 영역에 서 어려움을 겪으며 스스로 자신이 전반적인 양육능력이 부족 한 것으로 지각하고 있었다(Bae, 2013; N.-Y. Choi, Woo, Jung, Park, \& Yi, 2009; H.-K. Kim, 2009; Song, Shin, \& Lee, 2009).

최근 들어 결혼이주여성의 이러한 어려움이 알려지면서 전 국 시군구에 설치된 다문화가족지원센터에서는 한국어교육 과 부모교육 등을 제공해 이들의 자녀양육을 돕고 있으며, 인 터넷의 발달로 결혼이주여성들은 이와 관련된 자료들을 언제 든지 모국어로도 쉽게 찾아볼 수 있게 되었다. 그럼에도 불구
하고 자녀양육과 교육의 문제는 여전히 결혼이주여성들의 고 충으로 작용하여 부모역할에 대한 어려움과 양육에 대한 자신 감 결여, 부모역할 혼란 및 심리적인 부적응, 자녀염려에서 오 는 적응스트레스를 높게 경험하고 있는 것으로 나타났다(D.-

H. Kim, 2008; E. Kim, 2010; S.-H. Kim, 2011; S. H. Kim \& Noh, 2018). 이를 통해 자녀를 양육하는 것은 단순한 지식이나 정보 의 습득만으로 부족하며 양육을 성공적으로 수행할 수 있다고 믿는 신념과 관계된 양육효능감과 같은 요인이 실제 자녀를 양 육하는데 중요함을 알 수 있다(Coleman \& Karraker, 2003). 부 모의 양육효능감은 부모역할에 대한 적응을 돕고 자녀 양육 과 관련된 문제나 어려움을 관리해 나가도록 동기를 주는 작 용을 하는 중요한 인지적 특성으로, 양육효능감이 낮은 부모 는 양육지식을 갖고 있더라도 이를 행동으로 옮기지 못하고 정 서적 혼란을 겪을 뿐 아니라 일관적인 양육을 수행하지 못한다 (Coleman \& Karraker, 2003; Johnston \& Mash, 1989). 실제로 결 혼이주여성의 양육효능감이 낮은 경우, 양육행동에 부정적인 영향을 미치게 되고 이러한 환경에서 자라는 자녀들은 자기조 절능력, 유아교육기관의 적응 및 사회적 능력, 또래 유능성, 공 격성에 부정적 영향을 미치는 것으로 나타났으며, 이들의 양 육효능감을 향상시켜 주는 것이 자녀를 효과적으로 양육하는 방법으로 보고되고 있다(J. Kim et al., 2009; N.-H. Kim \& Baek, 2015; S. H. Kim \& Noh, 2018; S.-O. Kim \& Kim, 2016; Oh \& $\mathrm{Oh}, 2018)$. 따라서 양육효능감은 자녀양육에서 부모의 양육행 위를 예측할 수 있는 변인 중의 하나로(Choe, 2010), 자녀양육 에 많은 어려움을 호소하고 있는 결혼이주여성들에게 긍정적 인 양육을 이끌어내기 위해서는 먼저 양육효능감을 높일 수 있 는 보호요인에 대한 연구가 매우 필요하다.

보편적으로 어머니의 역할은 가족 내에서 세대 간 전이를 통해 자연스럽게 전수되지만, 결혼이주여성은 자신의 사회문 화적 기반에서 떨어져 나와 새로운 사회에서 자녀를 출산함으 로써 자신이 습득한 내용으로 자녀를 키울 수 없는 어려움을 겪게 된다(An, Hong, \& Kim, 2017). 따라서 이 시기 결혼이주 여성의 양육효능감에 영향을 미치는 요인으로 남편과 시댁을 포함한 가족의 지지가 중요한 역할을 하는 것으로 알려져 왔 다. 특히 결혼이주여성들은 임신 · 출산 및 한국생활과 관련된 정보를 주로 남편에게서 얻기 때문에 남편지지는 결혼이주여 성의 자녀양육에 가장 일차적인 지지체계가 되며, 양육효능감 에 긍정적인 영향을 미치게 된다(S. H. Kim, 2013; S. H. Kim \& Noh, 2018; S.-O. Kim \& Kim, 2016). 다음으로 결혼이주여성에 게 시댁가족의 지지는 시부모와 함께 생활하면서 동거와 부양 의 과정에서 시부모로부터 육아와 가사노동 등의 협력을 받음 
으로써 지지하고 배려하는 고부관계를 형성하여 양육부담을 낮추는 것으로 나타났다(Hong, 2013; S.-O. Kim \& Kim, 2016). 그러나 이와는 반대로 결혼이주여성들이 의사소통의 어려움 과 자녀양육에 대한 경험 부족, 낮선 한국의 삶의 방식으로 인 해 실질적인 주도권을 남편이나 시어머니에게 빼앗기는 경우 가 많아 가족지지가 양육효능감을 방해하는 것으로 나타났다 (S.-O. Kim \& Kim, 2016). 특히, 시어머니는 자신의 경험에 근 거한 육아방식을 주장하는 편이 많아 의견 차이가 발생하고 간 섭적이며, 다른 사람과 비교하는 등 상호작용을 통해 갈등 관 계에 있는 대상으로 보고되었다(H. Kim, 2010; J.-Y. Park, 2012; Yoon, 2005). 이렇듯 가족들이 자녀 양육에 대한 지지가 지나치 면 결혼이주여성들은 자녀양육에서 소외되거나 수동적으로 따라가면서 어머니로서의 정체성의 혼돈과 부모역할 수행에 무력감을 느끼게 되고 낮은 양육효능감을 갖기도 한다(J. Kim et al., 2009; S.-O. Kim \& Kim, 2016; Kong \& Yang, 2011).

한편 결혼이주여성의 가족지지로 남편과 시댁가족이 제시 되는 연구들과 달리 일부 연구에서는 친정가족도 사회적 지 지를 제공하고 있는 것으로 나타났다(S.-G. Lee, Park, Rho, \& Rhee, 2012). 즉, 결혼이주여성들이 한국에서 친정과 단절된 채 로 살아가는 것이 아니라 여전히 그들에게 친정의 지지는 사 회적 연결망으로써 작용하고 있음을 보여주고 있었으며, 특히 한국에 함께 거주할 경우 가사지원이나 재정지원 등과 같은 실질적인 서비스를 제공받는 경우가 많은 것으로 보고되고 있 다. 그러나 그 영향력은 남편과 시댁가족에 비해 작은 것으로 나타났다(H. Kim, 2010). 이러한 이유로 지금까지 결혼이주여 성의 가족지지에서는 남편과 시댁 중심으로 연구가 이루어져 있었으며, 더구나 친정지지와 자녀양육과 관련된 연구는 찾아 보기 어려운 실정이다. 그러나 결혼이주여성은 두 개의 사회문 화적 기반을 갖는 특성으로 인하여 자녀양육에 있어서 한국사 회의 남편 및 시댁가족의 지지와 모국기반인 친정가족의 지지 가 양육효능감에 각각 다른 영향을 미칠 것으로 예상할 수 있 다. 따라서 본 연구에서는 결혼이주여성에게 의미 있는 가족지 지의 차원으로 남편과 시댁뿐만 아니라 친정가족도 함께 고려 하여 양육효능감에 미치는 영향력을 탐색적 차원에서 살펴보 고자 한다. 또한 이러한 결과에 따라 가족지지의 대상에 따라 양육효능감에 미치는 영향의 차이를 비교하고자 한다.

다음으로 사회활동참여가 결혼이주여성들의 양육효능감에 영향을 미치는 주요 변인으로 알려져 왔다. 사회활동참여는 사 회구성원으로서 자신의 몫을 담당하며 사회적 존재로서의 정 체성을 갖게 하는 활동으로 특히 결혼이주여성들에게는 사회 활동참여가 개인이 주류사회에서 고립되어 주변화되는 것을
예방하는 핵심 기제이다(Berry, 1987; Palmore, 1981; Yang, 2010). 우선 사회활동참여는 결혼이주여성의 언어와 문화에 대한 접 촉과 상호작용을 넓힌다는 측면에서 적응의 밑거름이 된다. 한 국 거주기간이 늘어남에 따라 이들은 학부모회, 부녀회의 회원 이라는 특정한 지위를 획득하기도 하며 이는 또 다른 지역사회 활동 참여를 발생시켜 더 다양하고 복잡해진 관계망 안에 놓이 게 된다. 이러한 사회활동참여가 잘 이루어질 때 결혼이주 여성 들은 사회적 자본을 많이 갖게 되면서 이를 양육에 적극적으로 활용하고, 양육에 적극적으로 참여하면서 높은 수준의 효능감 을 갖는 것으로 알려져 있다(Jang, Chang, \& Yeum, 2015; A. M. Lee \& Rhee, 2017; Rhee, 2015). 이를 구체적으로 살펴보면, 양육 관련 부모교육 참여 여부와 부모교육 참여량은 결혼이주여성 의 양육효능감에 영향을 미치는 것으로 나타났다(J. Kim et al., 2009; Rhee, 2015). 또한 자녀양육에 필요한 자원을 동원할 수 있는 능력으로 선생님이나 다른 학부모와의 관계가 긍정적이 며, 학교 학부모활동 참여율이 높을수록 양육효능감이 높은 것 으로 나타났다(Rhee, 2015). 더불어 반드시 자녀와 직접 관련이 있는 활동이 아니더라도 사적모임, 직장모임, 지역사회기관 등 에 결혼이주여성이 적극적으로 관여할 때 양육효능감이 높아 지는 것으로 보고되었다(A. M. Lee \& Rhee, 2017).

다음으로 양육효능감에 영향을 미치는 요인으로 심리적 안녕감을 들 수 있다. 심리적 안녕감이란 자기를 있는 그대로 수용하고, 긍정적 대인관계를 유지하며, 자신의 행동을 스스 로 독립적으로 조절하는 능력이 있고, 자신을 둘러싼 환경을 효율적으로 통제하며, 뚜렷한 삶의 목적이 있으며, 자신의 잠 재능력을 실현시키는 강한 동기를 가지며, 좋은 삶을 살고 사 회에서 긍정적으로 기능하는 상태를 의미한다(Ryff \& Keyes, 1995). 결혼이주여성의 심리적 안녕감과 양육효능감의 관계 를 살펴보면 심리적 안녕감과 결혼이주여성의 양육효능감 간 에 유의한 정적상관이 있는 것으로 나타났다(S. H. Lee, 2016).

한편 위에서 살펴본 결혼이주여성의 양육효능감에 영향을 미치는 가족지지와 사회활동참여, 심리적 안녕감 간에도 상호 관련성이 있는 것으로 보고되고 있다. 즉, 가족의 지지는 사회 활동참여가 잘 이루어지도록 영향을 미치며, 심리적 안녕감 에도 영향을 미치는 것으로 나타났다(K. H. Choi, 2014; Ham, Jung, \& Kwon, 2009; Hwang, Moon, Yang, \& Jung, 2009). 결혼 이주여성들이 이주 초기의 고립감을 극복하기 위한 지역사회 활동 참여의 경로는 남편을 통해서 가장 많이 확보되었으며 (Hwang et al., 2009), 시부모, 남편, 자녀와 동거가족일 경우 결 혼이주여성의 지역사회활동과 자조모임 참여 경험의 비중이 높게 나타나 남편과 시부모가 사회활동참여에 영향을 미침을 
알 수 있다(K. H. Choi, 2014). 또한 가족구성원들의 지지가 높 을수록 결혼이주여성의 심리적 안녕감이 높게 나타났다(Ham et al., 2009). 심리적 안녕감과 사회활동참여 간에도 관련성이 있었는데 결혼이주여성들은 높은 수준으로 사회활동참여를 하였을 때 심리적 안녕감을 갖는 것으로 나타났다(S. L. Kim, 2010). 특히, 이주 후 불확실한 삶에서 출발하는 결혼이주여성 들은 사회활동참여를 통해 존재감을 찾고 삶의 활력소를 얻으 며 현실을 수용하고 타협점을 찾아 미래를 준비하는 것으로 나타났으며, 결혼이주여성의 문화적응스트레스가 사회활동 참여의 완전매개를 통해서 완충됨으로써 심리적 안녕감에 영 향을 주었다(Kwon, 2011; H.-H. Lee, 2010).

그러나 지금까지의 선행연구들은 가족(남편, 시댁, 친정)지 지와 사회활동참여, 심리적 안녕감이 양육효능감에 미치는 영 향력을 각각 살펴봄으로써 통합적으로 파악하는 것에 한계가 있다. 따라서 본 연구에서는 결혼이주 여성의 양육효능감에 영향을 미치는 변인들의 관계를 고려하여 가족(남편, 시댁, 친 정)지지와 양육효능감 사이에서 사회활동참여, 심리적 안녕 감이 순차적으로 직렬매개 하는 경로를 살펴보고자 한다.

본 연구의 문제는 다음과 같다.

\section{연구문제 1}

농촌지역 베트남 출신 결혼이주 여성의 남편지지와 양육효능감 의 관계에서 사회활동참여와 심리적 안녕감이 직렬매개 하는가?

\section{연구문제 2}

농촌지역 베트남 출신 결혼이주 여성의 시댁지지와 양육효능 감의 관계에서 사회활동참여와 심리적 안녕감이 직렬매개 하 는가?

\section{연구문제 3}

농촌지역 베트남 출신 결혼이주 여성의 친정지지와 양육효능감 의 관계에서 사회활동참여와 심리적 안녕감이 직렬매개 하는가?

\section{Methods}

\section{연구대상}

본 연구는 전국 9 개도 20 개 시군에서 읍.면지역에 거주하며 농업에 종사하는 한국인 배우자와 결혼하여 국내 농촌에 체류 하게 된 베트남 출신 결혼이주여성 198명을 대상으로 이루어
졌으며 연구대상자의 평균연령은 $31.48(S D=4.68)$ 세로 나타 났다. 연구대상자의 인구사회학적 특성은 Table 1 과 같다.

\section{연구도구}

\section{가족(남편, 시댁, 친정)지지}

가족(남편, 시댁, 친정)지지를 측정하기 위해 J.-W. Park (1985) 이 만든 사회적 지지 지각 척도를 근간으로 H. Yun (1993)이 부분 수정.보완한 가족지지 척도를 사용하였다. 본 척도는 총 25 문항으로 구성되어 있으며, 문항에 대해 전혀 아니다(1점) 에서 매우 그렇다(4점)까지 4점 Likert 척도로 측정하여 점수 가 높을수록 가족(남편, 시댁, 친정) 지지를 많이 받는다고 지 각하는 것으로 해석할 수 있다. 본 연구에서는 동일한 문항을 남편, 시댁, 친정에 대해 각각 평정하도록 하여 각각 남편지지 와 시댁지지, 친정지지 정도를 측정하였다. 가족지지는 결혼 이주여성이 인지한 가족들로부터 지지받고 있다고 느끼는 도 움으로 문항의 예로는 "내가 사랑과 보살핌을 받고 있다고 느 끼게 해준다."를 들 수 있다. 본 연구에서 나타난 가족지지에 대한 신뢰도 Cronbach's $\alpha$ 계수는 남편지지 .98 , 시댁가족지지 .98 , 친정가족지지 .96으로 나타났다.

\section{사회활동참여}

사회활동참여는 본 연구자가 농촌에 거주하는 결혼이주여성 의 사회활동참여를 관찰한 후 결혼이주여성의 사회활동참여 를 8개 영역(학부모 모임 또는 교육, 모국인 친구 모임, 마을 읍.면행사와 같은 주민 모임, 종교 활동 모임, 다문화가족지원 센터 모임 또는 교육, 농촌 여성기관·단체 활동, 취미 여가활 동모임, 작목반 모임 또는 영농교육 등의 직업 관련 모임)으로 나누어 농촌지역사회의 모임이나 활동에 어느 정도 참여하는 지를 묻는 문항으로 구성되었다. 본 척도는 거의 안함(1점)에 서 거의 참여(4점)까지 4점 Likert 척도로 점수가 높을수록 사 회활동참여를 많이 하는 것을 의미한다. 본 연구에서 사회활 동참여의 신뢰도 Cronbach's $\alpha$ 계수는 .85로 나타났다.

\section{심리적 안녕감}

심리적 안녕감에 대해 알아보기 위해 Ryff와 Keyes (1995)의 심리적 안녕감 척도(Psychological Well-Being Scale [PWBS])를 M.-S. Kim, Kim과 Cha (2001)가 표준화한 척도를 사용하였다. 
Table 1

Descriptive Statistics of Socio-Demographic Characteristics of Subjects Variables

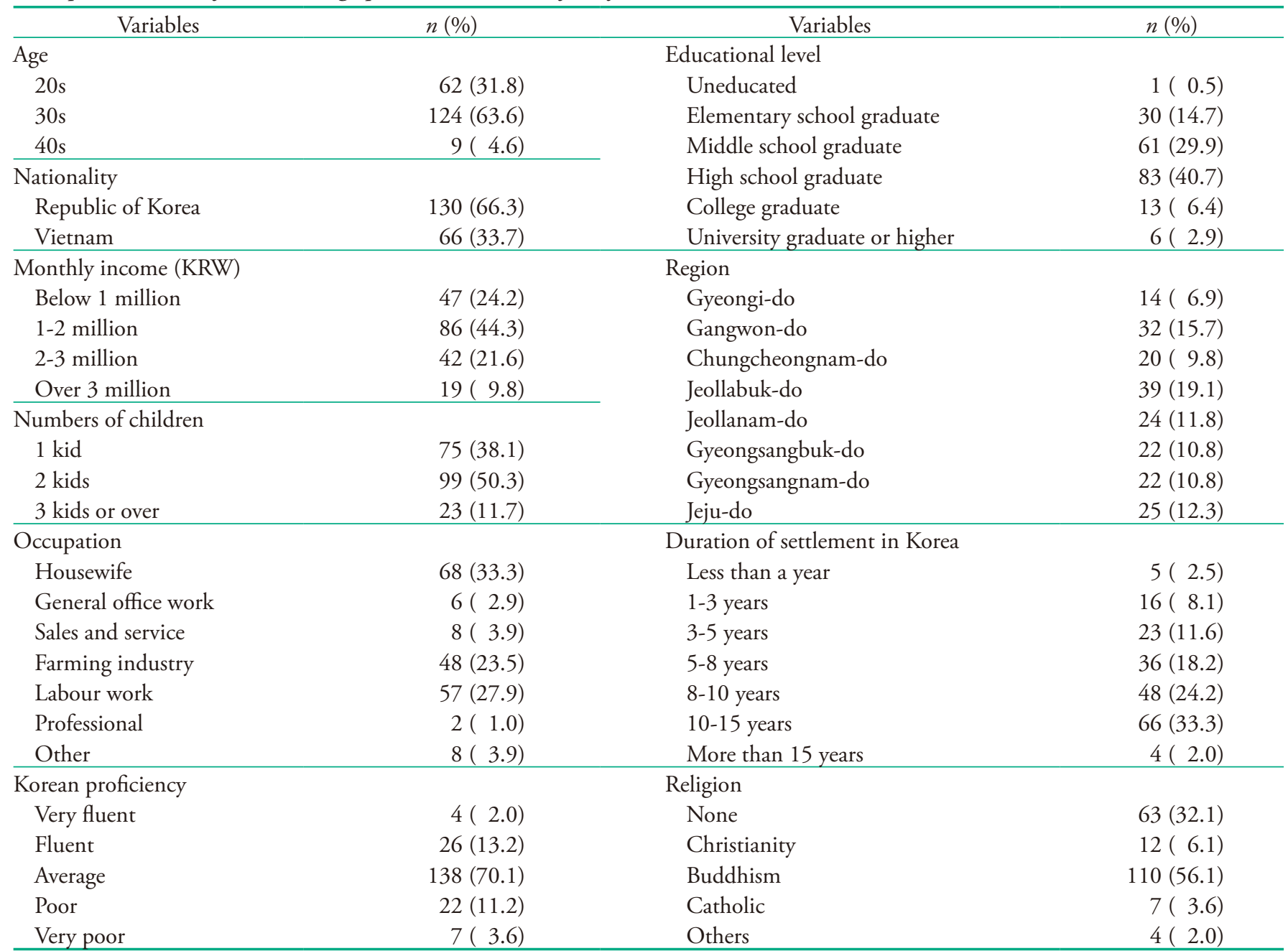

Note. $N=198$.

이 척도는 총 46 문항으로 긍정적인 내용 24 문항과 부정적인 내용 22문항으로 구성되어 있다. 본 연구에서는 부정적인 내 용을 역채점하여 점수가 높을수록 심리적 안녕감이 높은 것을 의미한다. 문항의 예로는 “살아온 내 인생을 돌이켜 볼 때 현 재의 결과에 만족한다."를 들 수 있다. 각 문항들은 4점 척도로 농촌에 거주하는 결혼이주여성들이 자신의 심리적 자원에 대 해 각각 그 일치 정도에 따라 전혀 아니다(1점)에서 매우 그렇 다(4점)까지의 범위로 평정하도록 되어있다. 본 연구에서 심 리적 안녕감의 Cronbach's $\alpha$ 계수는 .81로 나타났다.

\section{양육효능감}

본 연구에서는 양육효능감을 측정하기 위해 Giband-Wallston 과 Wandersman (1978)이 제작한 '양육효능감 척도(Parenting
Sense of Competence Scale [PSOC])'를 Shin (1997)이 번안한 척 도를 사용하여 측정하였다. 본 척도는 부모역할에서의 유능감 과 부모-자녀관계에서의 문제해결능력에 대한 어머니 자신의 기대를 측정하는 9문항으로 구성되었으며(H. J. Kim, 2014), 문항의 예로는 "나는 자녀를 돌보는 것에 유능하다고 생각한 다.”를 들 수 있다. 각 문항에 대해 전혀 아니다(1점)부터 매우 그렇다(4점)까지 4점 Likert 척도로 측정하였으며 점수가 높을 수록 양육효능감이 높음을 의미한다. 본 연구에서 양육효능감 의 Cronbach's $\alpha$ 계수는 .70으로 나타났다.

\section{연구절차}

본 연구는 2018년 3월 6일 생명윤리위원회의 승인을 받은 후 조사를 진행하였다. 설문지에는 연구목적 및 연구참여자가 알 
아야 하는 사항에 대하여 윤리위원회에서 규정하는 내용을 게 재하고 참여자에게 연구 동의를 얻은 후 진행하였다. 연구를 실시하기 전에 한국어로 된 질문지를 베트남어로 번역하고 이 를 다시 한국어로 번역하는 역번역 과정을 거쳐 2018년 3월 6 일에서 10 일까지 경북 안동시 길안면과 전북 부안군 하서면에 거주하는 베트남 출신 결혼이주여성 20명을 대상으로 예비조 사를 실시하였다. 예비조사 결과 문항을 이해하는데 문제점이 발견되지 않아 그대로 본조사를 실시하였다. 본조사는 3월 15 일부터 4월 25일까지 전국 각 도에서 분포되어있는 여성농업 인센터의 대표자들의 도움을 받아 실시되었다. 이를 위해 연구 자가 상담과 교육 관련 전문 역량을 갖춘 여성농업인센터 대표 자들을 사전에 만나 교육을 실시하고, 본 조사가 실시될 때 다 시 한 번 문서를 통해 조사내용을 전달한 후 자료를 수집하였 다. 그 결과 전국 9 개도 20 개 시군에서 읍.면지역에 거주하며 농업에 종사하는 한국인 배우자와 결혼하여 국내 농촌에 거주 하게 된 베트남 출신 결혼이주여성 209명을 대상으로 설문지 를 배포하였다. 총 204부가 수집되었고(회수율 97.6\%) 수거한 설문지 중에서 자녀가 없는 응답자 5 부와 불성실한 응답자 1 부를 제외한 198 부의 응답자료를 통계분석에 사용하였다.

\section{자료분석}

수집된 자료에 대한 통계 분석은 SPSS 22.0 (IBM Co., Armonk, $\mathrm{NY}$ )을 이용하여 자료에 대한 빈도분석과 신뢰도를 산출 하 였으며 변인들 간의 상관관계를 측정하였다. 그리고 결혼이 주여성의 가족(남편, 시댁, 친정)의 지지와 양육효능감의 관
계에서 사회활동참여와 심리적안녕감의 역할을 확인하기 위 해 SPSS PROCESS MACRO (Hayes, 2013) model 6을 사용하 여 직렬매개 분석을 실시하였다. 마지막으로 부트스트래핑 (bootstrapping)방법을 사용하여 간접효과의 유의성을 검증하 였다. 또한 PROCESS MACRO의 결과의 모든 효과는 비표준 화 계수(B)가 자료를 더 정확하게 반영한다는 Hayes (2013)의 제안에 따라 본 연구에서는 모든 효과를 비표준화 계수 $(B)$ 로 보고하였다.

\section{Results}

\section{기초분석}

먼저 Kolmogorov-Smirnov와 Shapiro-Wilk 검증을 통해 자료의 정규분포성을 확인한 결과 유의수준 .05에서 자료의 점수가 정 규분포를 따르는 것으로 나타났다. 다음으로 농촌지역 베트남 출신 결혼이주 여성의 남편지지와 시댁지지, 친정지지, 사회활 동참여, 심리적 안녕감, 양육효능감 간의 관계를 알아보기 위해 Pearson의 상관분석을 실시한 결과, 남편지지는 사회활동참여 와 심리적 안녕감, 양육효능감 사이에 정적상관이 있는 것으로 나타났다( $r s=.297 \sim .432, p<.001)$. 또한 시댁지지도 사회활동 참여와 심리적 안녕감, 양육효능감 사이에 정적상관이 있는 것 으로 나타났다 $(r s=.145 \sim .317, p<.05)$. 그리고 친정지지는 사 회활동참여와 심리적 안녕감 사이에 정적 상관이 있는 것으로 나타났으나 $(r=.155, p<.05)$, 양육효능감과는 유의미한 상관이

Table 2

Correlations Among Variables

\begin{tabular}{|c|c|c|c|c|c|c|}
\hline & 1 & 2 & 3 & 4 & 5 & 6 \\
\hline 1. Husband support & - & & & & & \\
\hline 2. Family-in-law support & $.713^{* * *}$ & - & & & & \\
\hline 4. Social participation & $.297^{* * *}$ & $.267^{* * *}$ & $.155^{*}$ & - & & \\
\hline 5. Psychological wellbeing & $.432^{* * *}$ & $.317^{* * *}$ & $.219^{* * *}$ & $.353^{* * *}$ & - & \\
\hline $\bar{M}$ & 3.230 & 2.861 & 3.299 & 2.288 & 2.843 & 3.024 \\
\hline$S D$ & .676 & .702 & .570 & .658 & .248 & .424 \\
\hline Skewness & -.839 & -.470 & -.646 & .368 & .111 & .054 \\
\hline Kurtosis & .237 & -.158 & .314 & -.270 & .353 & -.228 \\
\hline
\end{tabular}

Note. $N=198$.

${ }^{*} p<.05 .{ }^{* * *} p<.001$. 
나타나지 않았다 $(r s=.130 \sim .219, n s$; Table 2).

즉, 농촌지역 베트남 출신 결혼이주 여성의 높은 수준의 가 족지지(남편, 시댁, 친정)는 사회활동참여를 많이 하는 것과 심리적 안녕감을 갖는 것과 관련이 있는 것을 의미한다. 그리 고 남편지지와 시댁지지는 긍정적인 양육효능감을 갖는 것과 관련이 있으나 친정지지는 관련이 없는 것을 의미한다.

\section{농촌지역 베트남 출신 결혼이주여성의 남편 지지와 양육효능감의 관계에서 사회활동참여 와 심리적 안녕감의 직렬매개 효과}

농촌지역 베트남 출신 결혼이주 여성의 남편지지가 사회활동 참여와 심리적 안녕감을 거쳐서 순차적으로 양육효능감에 영 향을 미치는가를 알아보기 위해 PROCESS MACRO 6 model 을 활용하여 직렬매개 분석을 실시하였다. 이를 위해 농촌지 역 베트남 출신 결혼이주 여성의 남편지지를 독립변인으로,
양육효능감을 종속변인으로 설정한 후 사회활동참여를 제 1 매개변인으로, 심리적 안녕감을 제 2 매개변인으로 투입하였 다. 그 결과 남편지지는 양육효능감 $(B=.173, p<.001)$ 에 직접 적으로 영향을 미치는 것으로 나타났다. 그러나 사회활동참 여와 심리적 안녕감의 매개변인을 투입한 결과 남편지지는 양 육효능감에 직접적으로 영향을 미치지 않았으며 $(B=.082, n s)$, 남편지지가 사회활동참여 $(B=.288, p<.001)$ 에, 사회활동 참 여가 심리적 안녕감 $(B=.088, p<.001)$ 에, 심리적 안녕감은 양 육효능감에 $(B=.616, p<.001)$ 에 순차적으로 매개하는 것으로 나타났다. 즉, 농촌지역 베트남 출신 결혼이주 여성의 남편지 지가 직접적으로 양육효능감에 영향을 미치는 것이 아니라 사 회활동참여와 심리적 안녕감을 순차적으로 매개하여 양육효 능감에 영향을 미치는 것을 의미한다. 또한 농촌지역 베트남 출신 결혼이주 여성의 남편지지와 양육효능감 관계에 사회활 동참여와 심리적 안녕감을 더하면 총 설명량은 $21.2 \%$ 로 나타 났다 $(F=17.292[3,1109], p<.001$; Table 3, Figure 1).

Table 3

The Sequential Mediation Effects of Social Participation and Psychological Wellbeing on the Relationship Between Husband Support and Parenting Efficacy

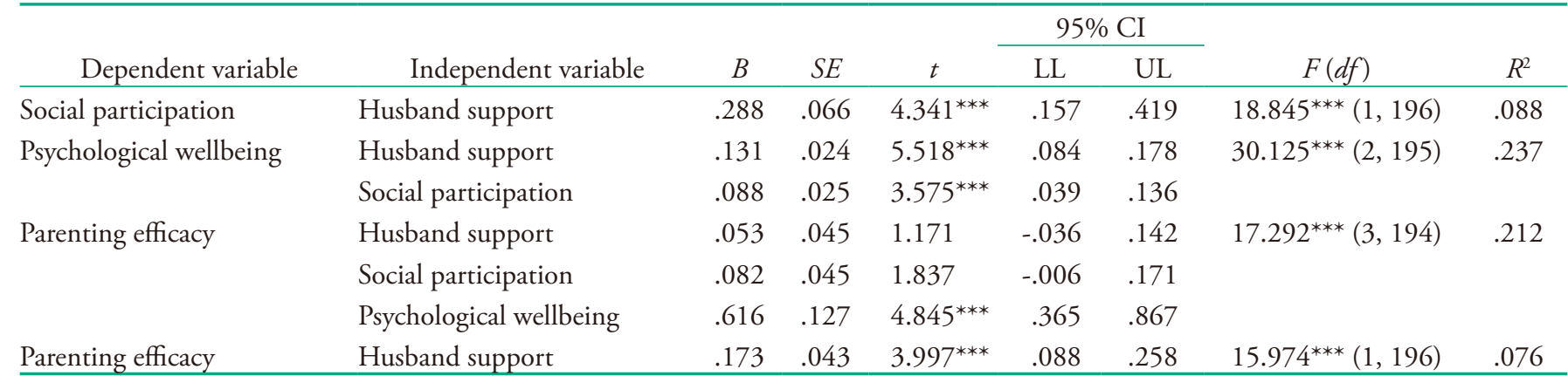

Note. $N=198$.

*** $p<.001$.

Table 4

Testing Indirect Effect of Social Participation and Psychological Wellbeing on the Relationship Between Husband Support and Parenting Efficacy

\begin{tabular}{|c|c|c|c|c|c|}
\hline & \multirow[b]{2}{*}{$B$} & \multirow[b]{2}{*}{$S E$} & \multirow[b]{2}{*}{$t$} & \multicolumn{2}{|c|}{$95 \% \mathrm{CI}$} \\
\hline & & & & LL & UL \\
\hline Total effect & .173 & .043 & $3.997^{* * *}$ & .088 & .258 \\
\hline \multicolumn{6}{|l|}{ Indirect effect } \\
\hline Total & .120 & .028 & & .069 & .179 \\
\hline $\mathrm{X} \rightarrow \mathrm{M} 1 \rightarrow \mathrm{M} 2 \rightarrow \mathrm{Y}$ & .016 & .008 & & .005 & .033 \\
\hline
\end{tabular}

Note. $N=198$. CI = confidence interval; $\mathrm{LL}=$ lower limit; $\mathrm{UL}=$ upper limit.

*** $p<.001$. 
한편 부트스트래핑 검증을 통해 총효과와 간접효과의 신뢰 구간을 추정한 결과 Table 4와 같이 농촌지역 베트남 출신 결 혼이주 여성의 남편지지와 사회활동참여, 심리적 안녕감이 양 육효능감에 미치는 총효과는 $B=.173$ ( $t=3.997, p<.001,95 \%$ CI $[.088, .258])$ 로 신뢰구간 0 을 포함하지 않아 유의미한 것으 로 나타났다. 또한 남편지지가 사회활동참여와 심리적 안녕감 을 통해 양육효능감에 영향을 미치는 간접효과 $(B=.016,95 \%$ CI $[.005, .033])$ 도 유의미한 것으로 나타났다(Table 4).

\section{농촌지역 베트남 출신 결혼이주여성의 시댁} 지지와 양육효능감의 관계에서 사회활동참여 와 심리적 안녕감의 직렬매개 효과

농촌지역 베트남 출신 결혼이주여성의 시댁지지와 양육효능 감의 관계에서 사회활동참여와 심리적 안녕감이 순차적으로 매개하는지 알아보기 위해 직렬매개 분석을 실시하였다. 그 결과 시댁지지는 양육효능감에 직접적으로 영향을 미치는 것 으로 나타났다 $(B=.087, p<.05)$. 그러나 사회활동참여와 심 리적 안녕감을 매개변인으로 설정한 결과 시댁지지는 양육효 능감에 미치는 영향이 유의미하지 않은 것으로 나타났다 $(B=$ $-.008, n s)$. 한편 시댁지지는 사회활동참여 $(B=.250, p<.001)$ 에, 사회활동참여는 심리적 안녕감 $(B=.109, p<.001)$ 에, 심리적 안 녕감은 양육효능감 $(B=.648, p<.001)$ 에 정적으로 영향을 미치 는 것으로 나타났다. 즉, 시댁의 지지는 양육효능감에 직접적 으로 영향을 미치는 것이 아니라 사회활동참여와 심리적 안녕 감을 순차적으로 매개하여 영향을 미치는 것을 의미한다. 또한 시댁의 지지와 사회활동참여, 심리적 안녕감은 양육효능감을 $19.7 \%$ 설명하는 것으로 나타났다(Table 5, Figure 2).
Table 6 를 보면 이러한 총효과와 간접효과의 신뢰구간을 검 증한 결과 총효과와 간접효과 모두 신뢰구간 0 을 포함하고 있 지 않아 유의미한 것으로 나타났다. 즉, 농촌지역 베트남 출신 결혼이주 여성의 시댁지지, 사회활동참여, 심리적 안녕감이 양육효능감에 영향을 미치는 총효과는 $B=.087(t=2.048, p<$ $.05,95 \% \mathrm{CI}[.003, .172])$ 로 나타났으며 시댁지지가 사회활동 참여와 심리적 안녕감을 통해 양육효능감에 간접적으로 영향 을 미치는 직렬매개 역시 유의미한 것으로 나타났다 $(B=.018$, 95\% CI [.006, .037]).

\section{농촌지역 베트남 출신 결혼이주여성의 친정 지지와 양육효능감의 관계에서 사회활동참여 와 심리적 안녕감의 직렬매개 효과}

농촌지역 베트남 출신 결혼이주여성의 친정지지와 양육효능 감의 관계에서 사회활동참여와 심리적 안녕감이 순차적으 로 매개하는지 알아보기 위해 직렬매개 분석을 실시하였다. Table 7과 Figure 3 를 보면. 친정지지는 양육효능감에 유의미 한 영향을 미치지 않는 것으로 나타났다 $(B=.096, n s)$. 그러나 친정지지는 사회활동참여 $(B=.179, p<.05)$ 에, 사회활동참여 는 심리적 안녕감 $(B=.123, p<.001)$ 에, 심리적 안녕감은 양육 효능감 $(B=.634, p<.001)$ 에 유의미한 영향을 미치는 것으로 나타났다. 즉, 친정의 지지는 사회활동참여와 심리적 안녕감 을 순차적으로 매개하여 영향을 미치는 것을 의미한다. 또한 친정의 지지와 사회활동참여, 심리적 안녕감은 양육효능감을 $19.8 \%$ 설명하는 것으로 나타났다. 이러한 총효과와 간접효과 의 신뢰구간을 검증한 결과 총효과는 신뢰구간 0 을 포함하고 있어 유의미하지 않은 것으로 나타났다 $(B=.096, t=1.829, n s$,

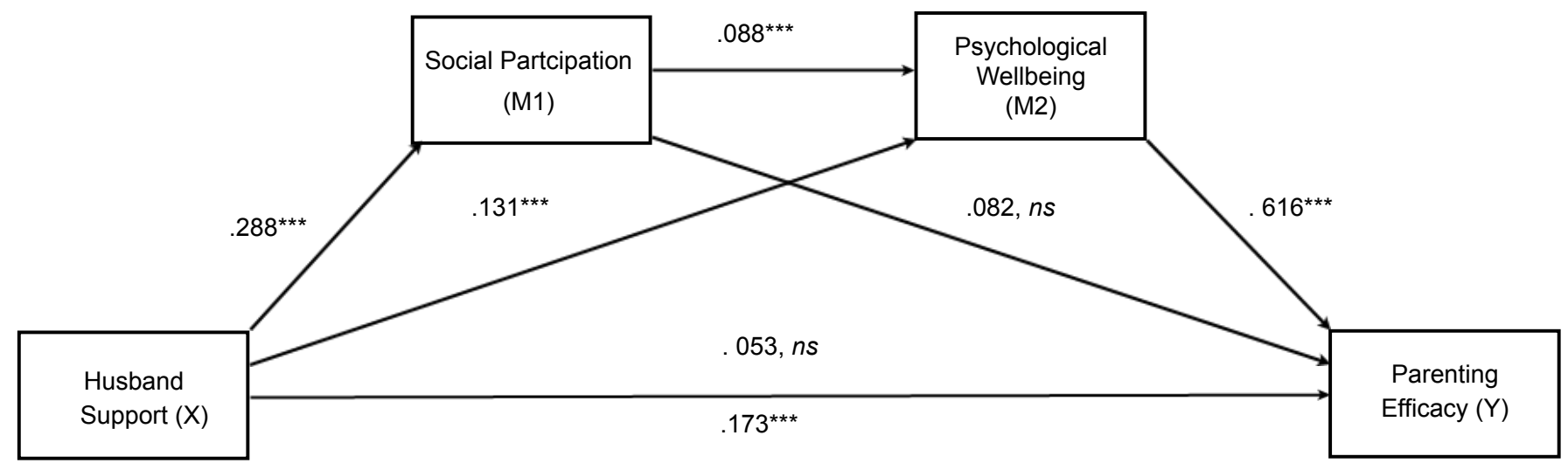

Figure 1. Diagram of paths from husband support to parenting efficacy.

${ }^{* * *} p<.001$. 
Table 5

The Sequential Mediation Effects of Social Participation and Psychological Wellbeing on the Relationship Between Family-In-Law Support and Parenting Efficacy

\begin{tabular}{|c|c|c|c|c|c|c|c|c|}
\hline \multirow[b]{2}{*}{ Dependent variable } & \multirow[b]{2}{*}{ Independent variable } & \multirow[b]{2}{*}{$B$} & \multirow[b]{2}{*}{$S E$} & \multirow[b]{2}{*}{$t$} & \multicolumn{2}{|c|}{$95 \% \mathrm{CI}$} & \multirow[b]{2}{*}{$F(d f)$} & \multirow[b]{2}{*}{$R^{2}$} \\
\hline & & & & & LL & UL & & \\
\hline Social participation & Family-in-law support & .250 & .065 & $3.884^{* * *}$ & .123 & .377 & $15.085^{* * *}(1,196)$ & .072 \\
\hline Psychological wellbeing & Social participation & .109 & .025 & $4.288^{* * *}$ & .059 & .159 & & \\
\hline \multirow[t]{2}{*}{ Parenting efficacy } & Family-in-law support & -.008 & .042 & -.186 & -.090 & .074 & $15.864^{* * *}(3,194)$ & .197 \\
\hline & Psychological wellbeing & .648 & .121 & $5.344^{* * *}$ & .409 & .888 & & \\
\hline Parenting efficacy & Family-in-law support & .087 & .043 & $2.048^{*}$ & .003 & .172 & $4.193^{*} \quad(1,196)$ & .021 \\
\hline
\end{tabular}

Note. $N=198$.

${ }^{*} p<.05 .{ }^{* * *} p<.001$.

Table 6

Testing Indirect Effect of Social Participation and Psychological Wellbeing on the Relationship Between Family-In-Law Support and Parenting Efficacy

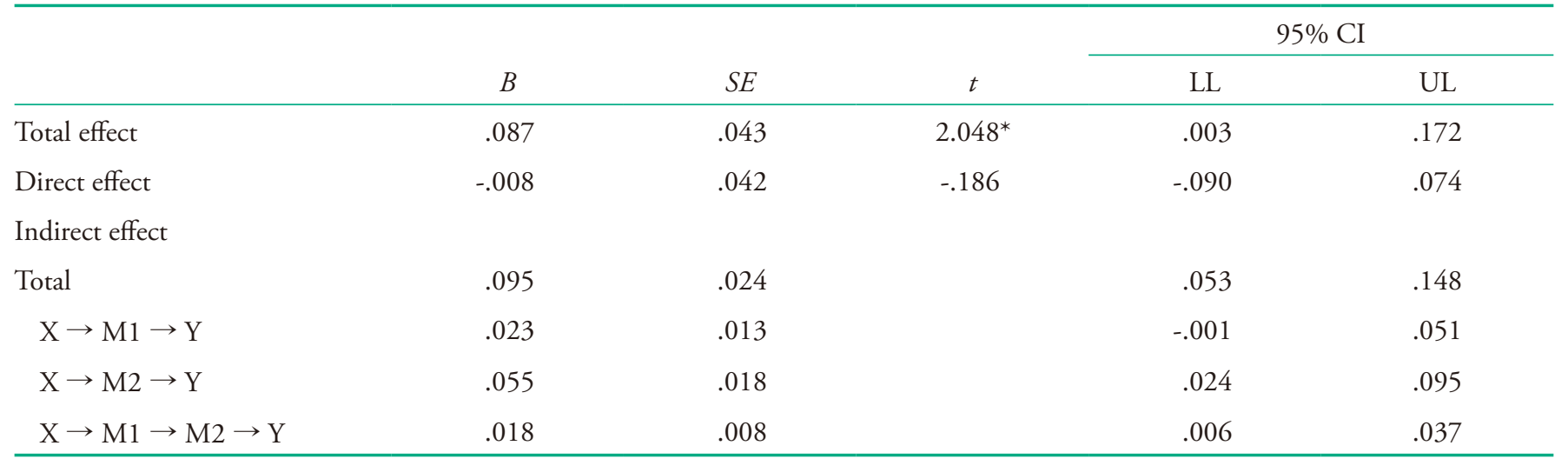

Note. $N=198 . \mathrm{CI}=$ confidence interval; $\mathrm{LL}=$ lower limit; $\mathrm{UL}=$ upper limit ${ }^{*} p<.05$.

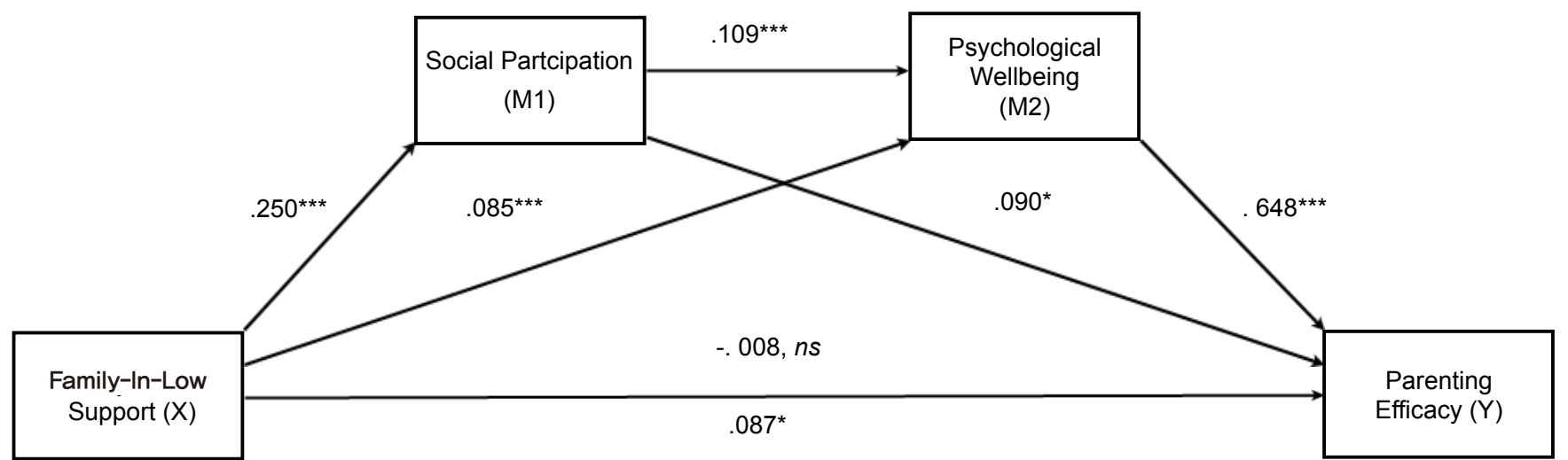

Figure 2. Diagram of paths from family-in-law support to parenting efficacy.

${ }^{*} p<.05 .{ }^{* * *} p<.001$. 
Table 7

The Sequential Mediation Effects of Social Participation and Psychological Wellbeing on the Relationship Between Family of Origin Support and Parenting Efficacy

\begin{tabular}{|c|c|c|c|c|c|c|c|c|}
\hline \multirow[b]{2}{*}{ Dependent variable } & \multirow[b]{2}{*}{ Independent variable } & \multirow[b]{2}{*}{$B$} & \multirow[b]{2}{*}{$S E$} & \multirow[b]{2}{*}{$t$} & \multicolumn{2}{|c|}{$95 \% \mathrm{CI}$} & \multirow[b]{2}{*}{$F(d f)$} & \multirow[b]{2}{*}{$R^{2}$} \\
\hline & & & & & LL & UL & & \\
\hline Social participation & Family of origin support & .179 & .081 & $2.201^{*}$ & .019 & .340 & $4.843^{*} \quad(1,196)$ & .024 \\
\hline & Social participation & .123 & .025 & $4.896^{* * *}$ & .074 & .173 & & \\
\hline \multirow[t]{2}{*}{ Parenting efficacy } & Family of origin support & .020 & .050 & 0.411 & -.077 & .117 & $15.920^{* * *}(3,194)$ & .198 \\
\hline & Psychological wellbeing & .634 & .120 & $5.308^{* * *}$ & .399 & .870 & & \\
\hline Parenting efficacy & Family of origin support & .096 & .053 & 1.829 & -.008 & .200 & $(1,196)$ & .017 \\
\hline
\end{tabular}

Note. $N=198$.

${ }^{*} p<.05 .{ }^{* * *} p<.001$.

Table 8

Testing Indirect Effect of Social Participation and Psychological Wellbeing on the Relationship Between Family of Origin Support and Parenting Efficacy

\begin{tabular}{lccccc}
\hline & & & & \multicolumn{2}{c}{$95 \%$ CI } \\
\cline { 4 - 6 } & $B$ & $S E$ & $t$ & LL & UL \\
\hline Total effect & .096 & .053 & 1.829 & -.008 & .200 \\
Direct effect & .020 & .049 & .411 & -.077 & .117 \\
Indirect effect & & & & .029 & .129 \\
Total & .076 & .026 & & -.003 & .042 \\
$\mathrm{X} \rightarrow \mathrm{M} 1 \rightarrow \mathrm{Y}$ & .016 & .012 & & .013 & .088 \\
$\mathrm{X} \rightarrow \mathrm{M} 2 \rightarrow \mathrm{Y}$ & .047 & .019 & .001 & .033 \\
$\mathrm{X} \rightarrow \mathrm{M} 1 \rightarrow \mathrm{M} 2 \rightarrow \mathrm{Y}$ & .014 & .008 & & & .001 \\
\hline
\end{tabular}

Note. $N=198 . \mathrm{CI}=$ confidence interval; $\mathrm{LL}=$ lower limit; $\mathrm{UL}=$ upper limit.

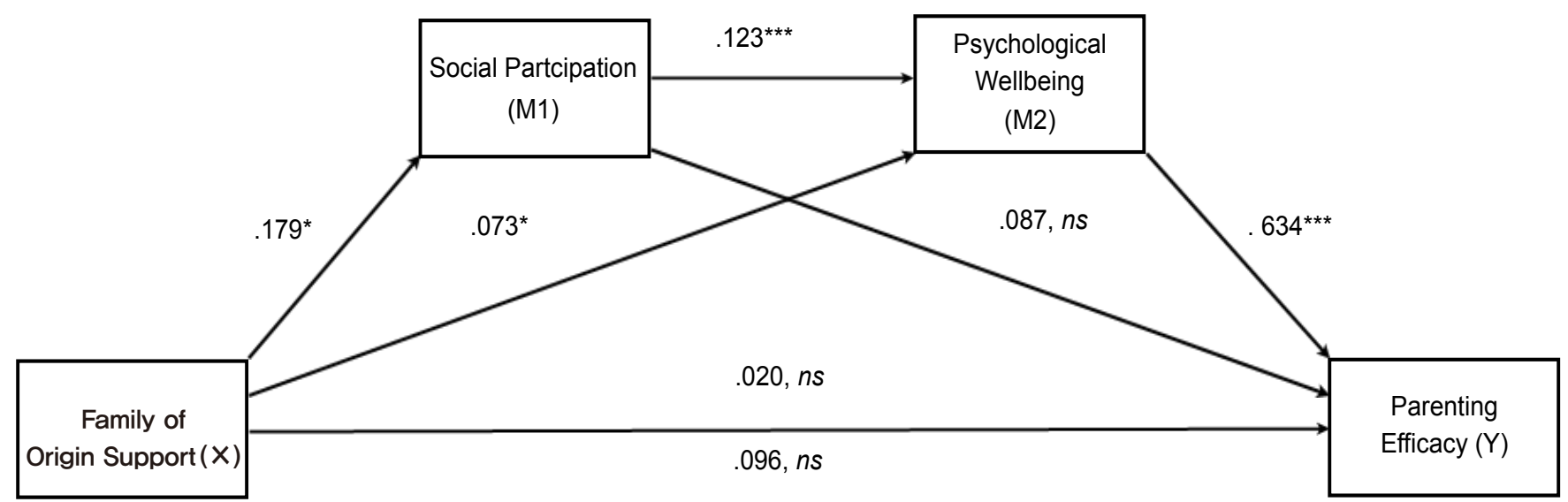

Figure 3. Diagram of paths from family of origin support to parenting efficacy.

${ }^{*} p<.05 .{ }^{* * *} p<.001$. 
$95 \%$ CI $[-.008, .200])$. 그러나 농촌지역 베트남 출신 결혼이주 여성의 친정지지가 사회활동참여와 심리적 안녕감을 통해 양 육효능감에 간접적으로 영향을 미치는 직렬매개는 유의미한 것으로 나타났다 $(B=.014,95 \%$ CI [.001, .033]; Table 8). 이처 럼 총효과가 통계적으로 유의미하지 않은 경우에도 간접효과 가 유의미하게 나타날 수 있다(Hayes, 2013).

\section{Discussion}

본 연구는 농촌지역에 거주하는 베트남 출신 결혼이주여성의 가족(남편, 시댁, 친정)지지와 양육효능감의 관계에서 사회활 동참여와 심리적 안녕감이 직렬 매개하는가를 알아보기 위해 남편, 시댁, 친정의 지지가 양육효능감에 미치는 직접효과와 간접효과를 검증하였다. 자료를 분석하여 얻어진 결과에 대한 요약과 논의는 다음과 같다.

첫째, 농촌에 거주하는 베트남출신 결혼이주여성의 남편지 지와 양육효능감 사이에서 사회활동참여와 심리적 안녕감의 직렬매개 효과에 대해 살펴보았다. 먼저 남편의 지지는 결혼이 주여성의 양육효능감에 직접적으로 영향을 미치는 것으로 나 타났다. 이는 결혼이주여성의 남편의 지지가 높을수록 긍정 적인 양육효능감을 갖는다는 선행연구와 일치하는 결과이다 (Choe, 2010; H. Choi, 2017; H. J. Kim, 2014; S. H. Kim \& Noh, 2018; S.-O. Kim \& Kim, 2016). 즉, 결혼생활에서 남편은 가장 중요한 가족지지의 원천으로, 남편의 지지는 결혼이주여성에 게 위안을 주고 어려움을 이겨내는 원동력으로 작용하며, 일차 적 지지체계로 작용하여 결혼이주여성의 양육효능감을 높인 다는 것을 의미하다. 다음으로 사회활동참여와 심리적 안녕감 을 매개변인으로 투입한 결과 남편지지는 양육효능감에 직접 적으로 영향을 미치지 않고 사회활동참여와 심리적 안녕감을 순차적으로 매개하여 양육효능감에 영향을 미치는 것으로 나 타나 직렬매개 효과를 검증하였다. 이러한 경로를 살펴본 연구 가 없기 때문에 직접적으로 선행연구와 비교하기는 어려우나 일부 변인 간의 관계를 설명한 선행연구들을 지지하는 결과라 고 볼 수 있다. 즉, 결혼이주여성의 남편지지를 통해 사회적 관 계 및 지지망을 형성한다는 Hwang 등(2009)과 H. Choi (2017) 의 연구와, 사회활동참여 수준이 높을수록 심리적 안녕감을 형 성한다는 S. L. Kim (2010)의 연구, 심리적 안녕감을 갖을수록 긍정적인 양육효능감을 갖는다는 S. H. Lee (2016)의 연구를 부 분적으로 지지하는 결과이다. 또한 이러한 결과는 배우자에게
속마음을 털어놓았을 때 우울도가 낮고 삶의 만족도가 높아져 심리적 안녕감에 영향을 친다는 선행연구(M.-A. Lee, 2010)에 서 나아가 결혼이주여성들이 삶의 터전이 되는 지역사회에 적 극적으로 참여하여 사회구성원으로 활동하게 될 때 역시 심리 적 안녕감을 갖는데 중요한 요소임을 확인할 수 있었다. 이러 한 결과들을 통합해서 살펴볼 때 결국, 농촌에 거주하는 베트 남 출신 결혼이주여성들에게 남편의 지지가 일차적 지지체계 로서 사회활동참여에 매우 중요한 역할을 하며 이를 통해 지역 사회활동에 참여함으로써 고립감을 극복하고 사회구성원으로 사회활동참여가 활발히 이루어질 때 심리적 안녕감을 갖고 비 로소 양육효능감을 갖는다는 것으로 해석할 수 있다.

둘째, 농촌에 거주하는 베트남출신 결혼이주여성의 시댁지 지와 양육효능감 사이에서 사회활동참여와 심리적 안녕감의 직렬매개 효과에 대해 살펴보았다. 먼저 농촌지역 베트남 출 신 결혼이주여성의 시댁지지는 양육효능감에 직접적으로 영 향을 미치는 것으로 나타났다. 이는 시댁지지가 육아와 가사 노동 등의 협력을 받음으로써 지지하고 배려하는 고부관계를 형성하여 양육부담을 낮추는 것으로 나타난 연구들을 지지하 는 결과이다(Hong, 2013; S.-O. Kim \& Kim, 2016). 즉, 시댁의 지지가 높을수록 결혼이주여성은 양육을 더욱 효율적으로 해 낼 수 있다는 신념을 형성하게 된다는 것을 의미한다. 다음으 로 사회활동참여와 심리적 안녕감을 매개변인으로 투입한 결 과 남편지지와 마찬가지로 시댁지지 역시 직접적인 효과가 사 라지면서 사회활동참여와 심리적 안녕감을 순차적으로 매개 하여 양육효능감에 영향을 미치는 것으로 나타나 직렬매개 효 과를 검증하였다. 이는 결혼이주여성이 도움을 필요로 할 때 가장 도움을 많이 주는 사람이 남편 다음으로 시어머니 순으 로 나타나 출신국 친구나 한국인 지인보다 시댁가족이 더 중 요하게 나타난 연구결과와 맥락을 같이 하고 있다(K.-S. Choi, 2006). 즉, 사회활동 참여를 할 때 시댁의 지지가 중요한 변인 이며 이를 통해 사회활동에 적극적으로 참여하고 지역사회에 소속감을 가질 때 심리적 안녕감을 갖고 양육효능감을 높일 수 있는 것으로 해석할 수 있다. 한편 몇 몇 연구에서는 결혼이 주여성에게 시댁가족 특히, 시어머니의 지지는 오히려 양육 효능감과 부정적인 관계를 갖는 것으로 알려져 왔다( J. Kim et al., 2009; Kong \& Yang, 2011). 즉, 지나친 시어머니의 지지는 오히려 자신의 양육방식을 고수하고 양육의 주도권을 차지하 여 결혼이주여성을 무기력하게 만드는데, 이처럼 직접적으로 과도하게 양육에 개입하는 것이 아니라 사회적 지지를 통해 시댁의 지지가 이루어질 때 심리적 안녕감을 형성함으로써 오 
히려 긍정적인 양육효능감을 형성하여 시댁지지 역시 양육효 능감의 보호요인으로 작용할 수 있음을 확인하였다.

셋째, 농촌에 거주하는 베트남출신 결혼이주여성의 친정지 지와 양육효능감 사이에서 사회활동참여와 심리적 안녕감의 직렬매개 효과에 대해 탐색적 차원에서 살펴보았다. 친정가족 의 지지는 농촌지역 베트남 출신 결혼이주여성의 양육효능감 에 직접적으로 영향을 미치지 않는 것으로 나타났다. 최근 들 어 친정가족이 한국에 와서 동거하는 경우가 많아지고 있으며 SNS의 발달로 친정가족과의 연락이 매우 용이해지고 있다. 그럼에도 불구하고 친정의 지지가 양육효능감에 직접적으로 영향을 미치지 않는 것으로 나타난 점은 자녀를 양육함에 있 어서 이주여성 자신의 원가족의 지지보다 현재가족인 남편의 지지와 농촌 특성상 생활 속에 밀착되어있는 시댁이 친정보다 더 영향력이 있음을 알 수 있었다. 그러나 사회활동참여와 심 리적 안녕감을 매개변인으로 투입한 결과 사회활동참여와 심 리적 안녕감을 순차적으로 매개하여 양육효능감에 간접적으 로 영향을 미치는 것을 확인하였다. 이는 직접적으로는 양육 효능감에는 영향을 미치지 않지만 사회활동참여를 높일 수 있 는 지지의 자원으로 친정의 지지 역시 중요하다는 것을 의미 한다. 이는 한국에서 친정과 단절된 채로 살아가는 것이 아니 라 여전히 그들에게 친정의 지지는 사회적 연결망으로써 작용 하고 있는 것을 확인한 S.-G. Lee 등(2012)의 연구를 일부 지지 하는 결과라고 할 수 있다. 즉, 다른 가족지지 체계와 마찬가지 로 친정지지 역시 사회활동 참여를 통해 존재감을 찾고 삶의 활력소를 얻으며 현실을 수용하여 심리적 안녕감을 높이고 이 를 통해 긍정적인 양육효능감을 형성하는 데 기여하는 것으로 해석할 수 있다.

마지막으로, 농촌에 거주하는 베트남 출신 결혼이주여성의 가족 지지가 사회활동참여와 심리적 안녕감을 직렬매개하여 양육효능감에 영향을 미치는 총 효과의 크기를 비교해보면 남 편지지, 친정지지, 시댁지지 순으로 나타났다. 이는 다른 연구 들이 시댁지지와 친정지지의 긍정적 영향에 대해서는 비일관 적인 결과를 보고하고 있는 반면에 남편의 지지는 일관적으로 긍정적 영향으로 보고하고 있는 것을 지지하는 결과다(Choe, 2010; H. Choi, 2017; S. H. Kim, 2013; S. H. Kim \& Noh, 2018; S.-O. Kim \& Kim, 2016). 즉, 남편의 지지가 자신이 거주하고 있는 한국에서의 사회적 참여와 적응에 매우 중요한 일차원적 지지체계로써 작용하고 있는 것을 보여주며, 그 만큼 남편지 지의 중요성을 입증하는 결과라고 볼 수 있다.

종합적으로 살펴보면, 이러한 결과는 농촌에 거주하는 베 트남 출신 결혼이주여성의 경우 가족(남편, 시댁, 친정)지지
가 양육효능감에 직접적으로 영향을 미치는 것이 아니라 이 러한 가족(남편, 시댁, 친정)의 지지가 사회활동에 적극적으로 참여하는 것과 심리적 안녕감을 갖는 것을 순차적으로 매개하 여 양육효능감에 영향을 미치는 간접효과가 있음이 검증된 것 이다. 즉, 농촌에 거주하는 베트남 출신 결혼이주 여성이 긍정 적인 양육효능감을 형성하기 위해서는 심리적 안녕감을 형성 하는 것이 중요하며, 이를 위해서는 보다 많은 사회활동참여 가 이루어져야 한다는 것을 확인하였다. 특히 언어와 문화차 이의 어려움을 안고 새로운 사회에 들어온 결혼이주여성이 불 안한 사회적 자아 정체성으로 한국생활을 시작할 수밖에 없지 만(Jang et al., 2015; A. M. Lee \& Rhee, 2017; Rhee, 2015), 그럼 에도 이들이 사회활동참여를 통해 자신의 존재감, 사회적 정 체성을 찾게 된다면 이들의 심리적 안녕감에 긍정적인 영향을 줄 수 있음을 확인하였다. 또한 이들이 사회활동 참여가 활발 하게 이루어지기 위해서는 남편과 시댁, 친정을 포함한 가족 의 지지가 필요함을 입증하였다. 즉, 농촌지역에 거주하는 베 트남 출신 결혼이주여성이 남편과 시댁, 친정의 지지가 높을 수록 이들의 사회활동참여가 활발하게 일어나 심리적 안녕감 에 긍정적으로 영향을 미치게 되고 이는 다시 자녀를 양육함 에 있어 효능감을 높게 갖게 되는 이중매개의 간접적 경로가 있음을 확인하였다.

이러한 결과는 농촌지역 결혼이주여성에 대한 교육 및 중 재 방안으로 활용될 수 있다. 즉, 농촌지역 결혼이주여성을 대 상으로 이루어지는 사업이나 프로그램에서 대상자를 다문화 가정의 가족 전체로 확대하여 가족 간의 지지방법이나 지지 기술을 습득하는 집단상담과 교육이 이루어져야 결혼이주여 성의 사회활동참여와 심리적 안녕감, 양육효능감을 높일 수 있음을 시사한다. 다음으로, 한국사회의 구성원으로서 잘 기 능하며 좋은 삶을 사는 것과 관련이 있는 심리적 안녕감과 같 은 개인 심리적 요인을 다루는 전문적인 상담 프로그램을 보 다 확대할 필요성이 있다. 이러한 과정에서 얻어지는 긍정적 인 변화는 결혼이주여성의 양육효능감을 높이는데 도움이 될 것으로 기대된다. 또한 높은 사회활동참여는 심리적 안녕감을 높게 가져서 양육효능감을 높게 하므로 읍·면단위의 많은 지 역기관에서에서 다문화가정 어머니를 대상으로 지역사회에 참여할 수 있는 기회를 수시로 제공하는 것이 필요하다.

본 연구의 결과와 논의를 토대로 정리한 제한점과 후속연 구를 위한 제언은 다음과 같다.

첫째, 본 연구의 조사를 위해 한국어로 된 설문지를 베트남 어로 번역하는 과정에서 문화적 맥락을 고려할 수 있는 전문 가의 의견이 반영되지 못하였다. 따라서 후속 연구에서는 연 
구 참여자의 문화적 맥락을 반영할 수 있는 수준을 갖춘 전문 가의 내용 검토의 과정을 거치는 작업이 요구된다.

둘째, 사회활동참여에 관한 설문지가 농촌지역에 맞는 척 도가 없어 연구자가 사회활동 영역을 구성하였다. 이를 보완 하기 위해 타당성을 확보하기 위한 연구가 필요하다.

마지막으로, 연구대상의 자녀들의 나이가 영아기부터 청소 년기까지 매우 다양하게 나타났으나 연구대상의 수가 적어 이 를 나누어 살펴보지 못하였다. 따라서 후속 연구에서는 농촌 지역에 거주하는 베트남 출신 결혼이주여성의 양육효능감과 동시에 자녀들의 발달단계를 고려할 필요가 있다.

이러한 제한점에도 불구하고 본 연구의 의의를 살펴보면 다음과 같다.

첫째, 결혼이주여성의 사회활동참여와 양육효능감, 심리적 안녕감과 양육효능감의 관계를 다룬 연구가 상대적으로 매우 부족한 가운데 특별히 본 연구는 농촌에 거주하는 베트남 출 신 결혼이주여성의 개인 심리적 변인, 가족 사회 관계변인과 양육효능감을 통합적으로 고찰한 데에 의의가 있다고 본다.

둘째, 선행연구에서 가족지지를 사회적 지지 차원에서 주 로 하나의 변인으로 연구한 데 반하여 본 연구는 가족지지를 남편지지, 시댁가족지지, 친정가족지지의 하위변인으로 탐구 하여 구체적인 접근을 시도하였다.

\section{Notes}

This article is a part of the first author's master's thesis submitted in 2018, and was presented at the 2018 Annual Autumn Conference of the Korean Association of Child Studies.

\section{Conflict of Interest}

No potential conflict of interest relevant to this article was reported.

\section{Ethics Statement}

All procedures of this research were reviewed by IRB (1040191201802-HR-002-01).

\section{References}

\section{In English}

Berry, J. W. (1987). Finding identity: segregation, integration, assimilation or marginality? In L. Driedger (Ed.), Ethnic Canada: Identities and inequalities (pp. 223-239). Toronto, CA: Copp Clark Pitman.

Coleman, P. K., \& Karraker, K. H. (2003). Maternal self-efficacy beliefs, competence in parenting, and toddlers' behavior and developmental status. Infant Mental Health Journal, 24(2), 126-148. doi:10.1002/imhj.10048

Gilband-Wallston, J., \& Wanderrsman, L. P. (1978, August). Development and utility of the parental sense of competence scale. Paper presented at the meeting of the American Psychological Association, Toronto, Canada.

Hayes, A. F. (2013). Introduction to mediation, moderation, and conditional process analysis: A regression-based approach. New York: The Guilford Press.

Johnston, C., \& Mash, E. J. (1989). A measure of parenting satisfaction and efficacy. Journal of Clinical Child Psychology, 18(2), 167-175. doi:10.1207/s15374424jccp1802_8

Palmore, E. (1981). Social patterns in normal aging: Findings from the duke longitudinal study. Durham, NC: Duke University Press.

Ryff, C. D., \& Keyes, C. L. M. (1995). The structure of psychological well-being revisited. Journal of Personality and Social Psychology, 69(4), 719-727. doi:10.1037/00223514.69.4.719

\section{In Korean}

An, S. Y., Hong, D., \& Kim, T. H. (2017). The effects of immigrant women's social support and parenting confidence on parenting satisfaction. Korean Journal of Human Ecology, 26(1), 1-20. doi:10.5934/kjhe.2017.26.1.1

Bae, K.-H. (2013). The effect of social participation on self-esteem and life satisfaction among married immigrant women. Korean Journal of Family Social Work, 41, 33-54.

Choe, H. S. (2010). Female international marriage immigrants' parenting self-efficacy: Focusing on Chinese, Filipinos, and Vietnamese. Journal of the Korean Home Economics Association, 48(7), 1-13. doi:10.6115/khea.2010.48.7.001

Choi, H. (2017). Factors affecting mothers' parenting efficacy in multicultural families: Moderating effect of perceived social discrimination. The Journal of Korea Open Association for Early Childhood Education, 22(2), 61-81. dol:10.20437/ KOAECE22-2-03

Choi, K. H. (2014). The effects of female marriage immigrants' 
cultural adaptation, social support and participation in social activities on their satisfaction of life (Doctoral dissertation). Retrieved from http://www.riss.kr/link?id=T13483471

Choi, K.-S. (2006). A study about the relationship between marriage satisfaction and social support of the female marriage immigrants-Centering Daegu \& Kyungbuk areas (Master's thesis). Retrieved from http://www.riss.kr/link?id=T10809283

Choi, N.-Y., Woo, H.-K., Jung, H.-S., Park, H.-J., \& Yi, S.-H. (2009). Mothers' parenting stress in multi-cultural families. Journal of Korean Home Management Association, 27(2), 255-268.

Chung, H.-S., Kim, Y.-S., Yi, T., Ma, K. H., Choi, Y., Park, G., ... Lee, E. (2016). An Analysis on the national survey of multicultural families 2015 (Report No. 2016-03). Retrieved from MOGEF website: http://www.mogef.go.kr

Ham, J., Jung, H., \& Kwon, M. (2009). Yeoseonggyeolhoniminjaui jaajonjunggamgwa sahoejeok jijiga simnijeok anjeonggame michineun yeonghyang [여성결혼이민자의 자아존중감 과 사회적 지지가 심리적 안정감에 미치는 영향]. Korean Journal of Local Government \& Administration Studies, 23(2), 329-348. doi:10.18398/kjlgas.2009.23.2.329

Hong, S.-H. (2013). International marriage immigrant women's resources for life adjustment in Korea. Journal of Korean Family Resource Management Association, 17(2), 121-145.

Hwang, J., Moon, K., Yang, H., \& Jeong, S. (2009). Daminjok - damunhwasahoeroui ihaengeul wihan jeongchaekpaereodaim guchuk (III): Yijumin-euy sahoitonghap-eulwihan jiyeoksahoi chamyeohyeonwhang-goa jeungjinbangan [다민족. 다문화사 회로의 이행을 위한 정책패러다임 구축(III): 이주민의 사회 통합을 위한 지역사회 참여현황과 증진방안](Report No. 2009-6-1). Retrieved from http://dlps.nanet.go.kr

Jang, D.-H., Chang, J.-W., \& Yeum, D.-M. (2015). The influence of marital satisfaction on parenting efficacy in marriage migrant women-focused on the mediating effects of acculturation and social capital. Korean Journal of Family Welfare, 20(4), 631-649. doi:10.13049/kfwa.2015.20.4.631

Kim, D.-H. (2008). A study of effect on parenting efficacy of immigrant women for marriage: Focusing on the mediating effect of acculturation (Doctoral dissertation). Retrieved from http://www.riss.kr/link?id=T11204587

Kim, E. (2010). The effect of marital interaction on the marital instability of foreign wives in Gyeongnam. Journal of Korean Home Management Association, 28(3), 1-12.

Kim, H. (2010). A study on social integration types of marriage migration females-Mainly those living in Busan. Kookmin Social Science Reviews, 22(2), 139-192.

Kim, H. J. (2014). Cognitive behavioral therapy for improving parenting efficacy of married immigrant women (Doctoral dissertation). Retrieved from http://www.riss.kr/link?id= T13528426
Kim, H.-K. (2009). The influence of general characteristics, perception of the culture gap, and cultural adaptation among mothers of young children in multicultural family on parenting efficacy. The Journal of Korea Open Association for Early Childhood Education, 14(5), 229-254.

Kim, J., Oh, J., Yoon, C., \& Lee, J. (2009). Married immigrant women's child-rearing experiences including parenting stress and parenting efficacy. Korean Parent-Child Health Journal, 12(1), 46-60.

Kim, M.-S., Kim, H.-W., \& Cha, K.-H. (2001). Analyses on the construct of Psychological Well-Being (PWB) of Korean male and female adults. The Korean Journal of Social and Personality Psychology, 15(2), 19-39.

Kim, N.-H., \& Baek, I.-K. (2015). The effect of child-rearing selfefficacy and parenting stress of married immigrant women on their children's preschool adjustment and social and peer competence. Early Childhood Education Research \& Review, 19(1), 365-384.

Kim, S.-H. (2011). A qualitative study on the problem of educating children in multicultural families. Journal of Korean Home Management Association, 29(4), 17-33.

Kim, S. H. (2013). A study on parenting attitudes of multi-cultural immigrant women (Master's thesis). Retrieved from http:// www.riss.kr/link?id=T13300184

Kim, S. H., \& Noh, Y. G. (2018). Influence of spousal support on the relationship between acculturative stress and sense of parenting competence among married vietnamese immigrant women. Korean Journal of Women Health Nursing, 24(2), 174-184. doi:10.4069/kjwhn.2018.24.2.174

Kim, S. L. (2010). A study on the ecological factors of the psychological well-being of marriage immigrant women (Master's thesis). Retrieved from http://www.riss.kr/link?id=T12113479

Kim, S.-O., \& Kim, H. (2016). Effects of support from spouse and family on the child fearing among marriage immigrant women. The Journal of the Korea Contents Association, 16(6), 462-473. doi:10.5392/JKCA.2016.16.06.462

Kong, S. Y., \& Yang, S. (2011). A qualitative study on the adaptation process of multicultural families. Korean Journal of Human Ecology, 20(1), 101-117.

Kwon, M. H. (2011). Effects of accumulative cultural stress of women migrated for marriage on their psychological wellbeing-Focused on mediating and moderating effects on psychosocial resources. Korean Comparative Government Review, 15(1), 275-302.

Lee, A. M., \& Rhee, C.-W. (2017). Community participation affects marriage immigrant women's parenting efficacy. Korean Journal of Family Social Work, 55, 237-263.

Lee, H.-H. (2010). A qualitative study on the community participation experiences of married immigrant women in rural areas. Korean Journal of Social Welfare, 62(3), 219-245. 
doi:10.20970/kasw.2010.62.3.009

Lee, M.-A. (2010). Effects of prior- and post-immigration networks on the psychological well-being of immigrant women in Korea. Health and Social Science, 27, 31-60.

Lee, S.-G., Park, H.-S., Rho, Y.-H., \& Rhee, C.-W. (2012), The mediated effects of acculturative stress and cultural capital on school adaptation for children in multicultural familiesFocused on the mediation effects of positive self-concept. Journal of the Korean Society of Child Welfare, 38, 235-264.

Lee, S. H. (2016). The effects of psychological well-being of married immigrant women on parenting efficacy (Master's thesis). Retrieved from http://www.riss.kr/link?id=T13988278

Lee, S. M., \& Lee, K. A. (2010). The effect of parenting stress and efficacy in mothers of multicultural family on their parenting behavior. Journal of Future Early Childhood Education, 17(3), 71-105.

Ministry of Gender Equality and Family. (2018). Damunhwagajok gwallyeon yeondobyeol tonggye [다문화가족 관련 연도별 통 계]. Retrieved from September 30, 2018, from http://www. mogef.go.kr

Oh, E.-J., \& Oh, M.-J. (2018). The effect of parenting stress and acculturative stress on parenting efficacy in Vietnamese married immigrant women. Journal of the Korean Society of Maternal and Child Health, 22(2), 96-105. doi:10.21896/ jksmch.2018.22.2.96

Park, J.-W. (1985). A study to development a scale of social support (Doctoral dissertation). Retrieved from http://www.riss.kr/ link?id=T1791002

Park, J.-Y. (2012). The mediating effect of hope between family-related stress and the psychological wellbeing of women immigrants. Korean Journal of Family Welfare, 17(4), 199-216.

Rhee, C. (2015). Impact of social capital on married immigrant women's parenting in South Korea. Korean Journal of Social Welfare, 67(1), 239-261. doi:10.20970/kasw.2015.67.1.010

Seol, D.-H., \& Yoon, H.-S. (2008). Socioeconomic adaptation and welfare policy for immigrant women on marriage: Similarities and differences among countries of origin. Korean Social
Security Studies, 24(2), 109-133.

Shin, S. J. (1997). Effects of stress, social support and efficacy on mothers' parenting behaviors (Doctoral dissertation). Retrieved from http://www.riss.kr/link?id=T3628454

Song, M., Lee, E., \& Shin, H. (2009). The development of a group counseling program for enhancing foreign mother's parenting efficacy in a multicultural family. The Korea Journal of Counseling, 10(3), 1627-1643. doi:10.15703/ kjc.10.3.200909.1627

Statistics Korea. (2018). 2017 Damunhwa ingu dongtae tong-gye. [다문화 인구 동태 통계]. Retrieved from April 25, 2018, from http://kostat.go.kr

Yang, S.-M. (2010). An effects of the participation attitude in each social activity on life satisfaction of married immigrant women in a Korean rural area. The Journal of Rural Society, 20(1), 233-263.

Yun, H. (1993). A perception of everyday stress and social network support in adolescence (Master's thesis). Retrieved from http://www.riss.kr/link?id=T40085

Yoon, H.-S. (2005). Conflicts and adjustments of foreign wives married to Korean men: Filipina wives in rural Korea. Journal of Local History and Culture, 8(2), 299-339. doi:10.17068/lhc.2005.11.8.2.299

\section{ORCID}

In Ok Park

Ung Im Park

Eun Gyoung Lee http://orcid.org/0000-0002-7171-7493

http://orcid.org/0000-0001-6637-0918

http://orcid.org/0000-0001-6935-6804
Received April 30, 2019

Revision received May 22, 2019

Accepted May 27, 2019 